\title{
THE NECESSITY FOR REVISITING DIRECT CORPORATE HUMAN RIGHTS OBLIGATIONS IN THE CURRENT BUSINESS AND HUMAN RIGHTS TREATY PROCESS
}

\author{
Philippa Osim Inyang \\ Faculty of Law, University of Calabar \\ Email: osiminyang@unical.edu.ng
}

Cite this article:

Philippa Osim Inyang (2021), The Necessity for Revisiting Direct Corporate Human Rights Obligations in the Current Business and Human Rights Treaty Process. African Journal of Law, Political Research and Administration 4(2), 71-87. DOI: 10.52589/AJLPRAESI4CHIQ.

\section{Manuscript History}

Received: 3 Nov 2021

Accepted: 5 Nov 2021

Published: 14 Dec 2021

Copyright $\odot 2020$ The Author(s). This is an Open Access article distributed under the terms of Creative Commons AttributionNonCommercial-NoDerivatives 4.0 International (CC BY-NC-ND 4.0 ), which permits anyone to share, use, reproduce and redistribute in any medium, provided the original author and source are credited.
ABSTRACT: The international community has awoken to the reality that transnational corporations (TNCs) do not only control more resources than a good number of states. They wield enormous influence in the corporate world which greatly impacts on local cultures and initiatives. Many of these TNCs, who operate in developing states, engage in activities which frequently result in human rights abuses. Several states rely on the resources extracted by these large corporations as the main stay of their economies. Consequently, they lack the economic capacity and political will to effectively regulate the activities of the TNCs, leaving these entities to perpetrate human rights abuses in the local communities with impunity. Although the Human Rights Council, through the Inter-governmental working group on Business and Human Rights, has begun a treaty process on business and human rights to address these issues, the work of the $I G W G$, so far, has not adequately responded the root cause of the corporate impunity, which is their unwillingness and inability to hold corporate entities accountable for their harmful activities. Thus, this paper proposes that the issue of direct human rights obligations on corporate entities should be revisited in order to ensure that corporate entities do not escape accountability for human rights harm resulting from their activities.

KEYWORDS: Direct Obligations, Business and Human Rights, Transnational Corporations, Corporate Impunity, Corporate Abuse 


\section{INTRODUCTION}

The international community has awoken to the reality that transnational corporations (TNCs) do not only control more resources than a good number of states. They wield enormous influence in the corporate world which greatly impacts on local cultures and initiatives. Many of these TNCs, who operate in developing states, engage in activities which frequently result in human rights abuses. Several states rely on the resources extracted by these large corporations as the mainstay of their economies. Consequently, they lack the economic capacity and political will to effectively regulate the activities of the TNCs, leaving these entities to perpetrate human rights abuses in the local communities with impunity. Several international regulatory initiatives have been adopted to fill in the regulatory gaps; however, they have been criticized as being mere political commitments which lack the necessary legal binding force to ensure their implementation and enforcement. Following several calls from civil society, the Human Rights Council at its 26th session in July 2014, established an openended intergovernmental working group (IGWG) to elaborate on an international legally binding instrument on business and human rights to ensure that the activities of TNCs are effectively regulated. ${ }^{1}$ So far, the IGWG has published an Elements document and three Drafts of the proposed binding instrument. The Drafts, like current soft law initiatives, focus on States as the enforcers of the rights and obligations within the future binding instrument, losing sight of the fact that it is the very failure of the State in executing its obligations that led to the treaty process in the first place. Against this background, this paper proposes that in order to ensure genuine accountability for corporate human rights abuse and address the problems of States' unwillingness, inability and even complicity in human rights abuses by corporate entities, direct corporate obligations should be brought back to the negotiation table.

\section{THE RATIONALE FOR DIRECT CORPORATE OBLIGATIONS}

Questions relating to the accountability of transnational corporate entities for their harmful activities arose from the 1980's which witnessed a progressive elimination of barriers to trade and investment and a growing mobility of capital across national boundaries. ${ }^{2}$ Sectors like production, manufacturing, and finance moved beyond the exclusive confines of states and became increasingly dominated by corporations who were the major drivers of this development. ${ }^{3}$ In order to take advantage of this process of economic globalisation, many developing states embraced foreign direct investment (FDI) as a necessary initiative for expanding their economies. ${ }^{4}$ Consequently, the corporate entities, whose parent companies are usually based in developed states such as the US, Canada and countries in the EU, moved to set up operations across state boundaries, often through subsidiaries. This led to an expansion of the size and influence of the transnational corporate entities internationally. ${ }^{5}$ Presently, over half of the world's one hundred largest economies are corporate entities who have relatively

\footnotetext{
${ }^{1}$ UN Human Rights Council, Elaboration of an international legally binding instrument on transnational corporations and other business enterprises with respect to human rights 25 June 2014 A/HRC/26/L.22/Rev.1, para 1.

2 Justice M Wilcox 'Foreword' in M. Jones and P. Kriesler eds., Globalization, Human Rights and Civil Society (Prospect Media, 1998), 6.

3 ibid

${ }^{4}$ Scott Jerbi 'Business and Human Rights at the UN: What Might Happen Next?' (2009) 31 Human Rights Quarterly 299, 303.

${ }^{5}$ David Kinley and Junko Nolan 'Trading and Aiding Human Rights: Corporations in the Global Economy' (2007) 25 Nordic Journal of human rights Law 4, 358.
} 
more power than the governments of the states in which they operate. ${ }^{6}$ They now directly and indirectly influence negotiations over issues ranging from trade to national and international economic policy. ${ }^{7}$ Their role in the globalised world has become too important to be ignored.

The impact of the activities of transnational corporate entities has strong bearings on human rights. Through the commercial activity driven by corporate entities, jobs and wages are made available, goods and services are provided, which enable states to provide further goods and services for individuals. This positively influences a wide range of human rights including the rights to food, health, education, work, shelter and the freedom of movement. ${ }^{8}$

However, the economic power and influence of transnational corporate entities has worked like a double-edged sword. They have also recorded serious negative impacts on human rights in the pursuit of corporate investments in the states where they operate. ${ }^{9}$ The antecedents of Shell in Nigeria's Niger Delta, Texaco in Ecuador, and Union Carbide in India - incidents which resulted in mass deprivation of the entire range of human rights- are all testaments to the scope and scale of human rights harm that transnational corporate entities are capable of causing. ${ }^{10}$ The threat that these corporate entities pose to the enjoyment of human rights have been considered to be greater than that coming from some states. ${ }^{11}$

Irrespective of their positions of strong economic and political advantage, no corporate entity operates outside a formal obligation to respect the laws of the states where they operate. However, human rights law has always focused on the state, because the state was seen as the only entity that was capable of greatly impacting the human rights of individuals. Thus, the state was given the primary obligation to protect, respect and fulfil human rights. ${ }^{12}$ Nevertheless, the human rights obligation to protect as contained in the various human rights instruments, has been interpreted to entail the states' duty to prevent third parties, including transnational corporate entities from engaging in conduct that impacts negatively on human rights. ${ }^{13}$ Yet, at the time of drafting, these human rights instruments did not contemplate the emergence of powerful corporate entities that would rival the states' influence on the human rights of individuals. Consequently, they do not adequately address the peculiarities of the corporate entities' unique transnational character.

\footnotetext{
${ }^{6}$ As of the year 2020, 69 of the richest entities in the world were companies and not countries. See B. Stauffer, 'Holding companies to account: Momentum builds for corporate human rights duties (Human Rights Watch, 2020) < https://www.hrw.org/world-report/2020/country-chapters/global-2\# > accessed 17 September 2021.

7 ibid

8 ibid

${ }^{9}$ Amnesty International, 'Corporations' (Amnesty International.org) <https://www.amnesty.org/en/what-we-do/corporateaccountability/> accessed 15 September 2021.

${ }^{10}$ See generally, S. Joseph, 'Protracted lawfare: The tale of Chevron Texaco in the Amazon' (2012) 3 Journal of Human Rights and the Environment 1; J. Kimmerling, 'Indigenous People and the Oil Frontier in the Amazon: The case of Ecuador, Chevron Texaco and Aguinda' (2006) International Law and Advocacy 413; A. Idowu, 'Human Rights, Environmental Degradation and Oil Multinational Companies in Nigeria: The Ogoniland Episode' (1999) 17 Netherlands Quarterly of Human Rights 2; M. Ezeudu, 'Revisiting Corporate Violations of Human Rights in Nigeria's Niger Delta Region: Canvasing the Potential Role of the International Criminal Court' (2011) 11 African Human Rights Journal 1; and L. Kalinoe and M. J. Kuwimb, 'Customary LandOwners Right to Sue for Compensation in Papua New Guinea and the Ok Tedi Dispute' (1997) 25 Melanesian Law Journal 65, 2.

${ }^{11}$ D. Shelton, 'Protecting Human Rights in a Globalized World' (2002) 25 Boston College International and Comparative Law Review 2, 279-280.

${ }^{12}$ UNHCHR, 'Report by the Special Representative of the United Nations Secretary General on the issue of Human Rights and Transnational Corporations and Other Business Enterprises' (Report No. III, June 2007).

13 ibid
} 
Most transnational corporate entities carry out their operations in resource rich developing states, who lack the political will to effectively regulate corporate activities so as not to discourage corporate investments. ${ }^{14}$ Even in the rare situations where the host states are willing to regulate corporate activities, many of them are incapable of initiating the necessary legal procedures, as they lack the financial resources and functioning, non-corrupt court systems, which are necessary to conduct effective investigations. ${ }^{15}$

As a result of the relative imbalance of power coupled with the dependence of developing states on the presence of transnational corporate entities, victims of human rights abuses turn to the developed states, who are home to about 90 percent of the parent companies of the transnational corporate entities. ${ }^{16}$ These countries are known to have better domestic regulatory structures. ${ }^{17}$ Some home states like the US, the UK, France, Canada and Australia have actually made attempts at using their domestic legislation to ensure that their transnational corporate entities are held accountable for the actions of their foreign subsidiaries. ${ }^{18}$ However, these regulatory efforts have been unsuccessful. At present the protection of human rights is an obligation that states undertake with respect to the activities of persons located within their territories. There is currently no express provision in any human rights instrument that mandates states to extend the obligation to protect extraterritorially. ${ }^{19}$ Home states fear that an individual extension of the obligation to protect the activities of the foreign subsidiaries of their corporate nationals would place them at a competitive disadvantage in relation to other states who may not see the need to extend their regulations to regulate their TNCs activities. ${ }^{20}$

Beyond this, the corporate form itself also poses regulatory challenges. Legally speaking, the parent company located in the home state is considered separate and distinct from its subsidiaries and other corporate affiliates, even where they may actually be subject to uniform control. ${ }^{21}$ Accordingly, the subsidiaries which operate in the developing states are considered to be independent from their parent companies as separate corporate bodies, and are subject to the national legal order of the host state. Thus, any attempt by the home state to extend its regulations over the activity of a foreign subsidiary may be considered as an interference on the sovereignty of the host state. ${ }^{22}$ As there is no obligation on home states to extend human rights protection extraterritorially, they are usually reluctant to do so in order not to infringe on

\footnotetext{
${ }^{14}$ P. Simons and A. Macklin, The Governance Gap: Extractive Industries, Human Rights and Home State Advantage (London, Routledge 2014), Chapter 4.

15 ibid

${ }^{16} \mathrm{M}$. Weschka, 'Human rights and multinational enterprises: how can multinational enterprises be held responsible for human rights violations committed abroad?' 66 Zeitschrift für auslandisches offentliches Recht und Volkerrecht 3, 629. 17 ibid.

${ }^{18}$ See French Due Vigilance Law 2017, available at < https://www.business-humanrights.org/en/latest-news/french-duty-ofvigilance-law-english-translation/> accessed 17 September 2021; Australian code of Conduct Bill 2000, <http://www.austlii.edu.au/au/legis/cth/bill/ccocb20002002248/> accessed 17 August 202; US Corporate Code of Conduct Act, 1 H.R. 4596 (106 ${ }^{\text {th }}$ Congress Session): Corporate Code of Conduct Act, 7 June 2000 <https://www.govtrack.us/congress/bills/106/hr4596/text> accessed 14 November 2016; Corporate Responsibility Bill (UK Bill), Bill no.129 of 2003; Bill C-300, An Act respecting Corporate Accountability for the Activities of Mining, Oil or Gas in Developing Countries, http://www.parl.gc.ca/HousePublications/Publication.aspx?Language=E\&Mode=1\&DocId=3658424 accessed 2 September 2021.

${ }^{19}$ International law recognises the right, but not the obligation of states to exercise extraterritorial jurisdiction over their nationals committing wrongs abroad.

${ }^{20}$ S. Joseph, 'Taming the Leviathans: Multinational Enterprises and Human Rights' (1999) 46 Netherlands International Law Review 2, 184

${ }^{21}$ M. Weschka Supra n 16, at 629-630.

22 ibid
} 
the sovereignty of the host states. ${ }^{23}$ Another related challenge is the doctrine of forum non conveniens, which presents the courts of a state with the 'discretion to decline to hear a case when there exists a foreign court more appropriately suited to hear the matter' ${ }^{24}$

Following the challenges confronting host state and home state human rights regulation, attempts have been made to establish an international framework that specifically addresses the problems with regulating the activities of corporate entities as they affect human rights. A number of voluntary initiatives on corporate social responsibility have been established in this regard. Most of these initiatives are based on a set of principles, including human rights and/or labour rights, that participating companies and states voluntarily commit to respect in their operations and within their spheres of influence. The structure of these initiatives varies. This thesis will focus on six of the most prominent of these initiatives- the UN Draft Code of Conduct for Transnational Corporations, the ILO tripartite obligations, the OECD Guidelines on Multinational Enterprises, the UN Global Compact, the UN Draft Norms on the Responsibilities for Transnational Corporations and Other Business Enterprises, and the UN Guiding Principles on Business and Human Rights. ${ }^{25}$

These initiatives have however been criticised as being too 'soft' because they lack any power to sanction companies when they fail to respect the principles and standards that the initiatives establish. Human rights activists have insisted that instead of focusing on voluntary soft law initiatives, a regulatory framework, which prescribes formal obligations, liabilities and sanctions, should be established. Such a framework was previously attempted with the proposed establishment of the UN Draft Norms on Transnational Corporations. ${ }^{26}$ The Norms sought to place direct international human rights obligations on transnational corporate entities comparable to those of states. However, the Norms never saw the light of day as they were unable to garner enough support for its establishment.

Out of all the current regulatory initiatives, the UN Guiding Principles is said to have gained wide support amongst states and corporate entities, who have included them in their internal policies. The Guidelines build on the 'Protect, Respect and Remedy' framework established by former Special Representative to the UN Secretary General, Professor John Ruggie. ${ }^{27}$ The Framework requires that states take steps to prevent human rights abuse by corporate entities; and places a responsibility to respect human rights on corporate entities. ${ }^{28}$ This responsibility entails a requirement that they undertake human rights due diligence in their business

\footnotetext{
${ }^{23}$ ibid

${ }^{24}$ S. Joseph, Supra n 19, at 178.

${ }^{25}$ UN Draft Code on Transnational Corporations (12 June 1990) UN Doc. E/1990/94; OECD, Guidelines for Multinational Enterprises, 15 ILM 969 (1976) annex to the OECD Declaration on International Investment and Multinational Enterprises, 21 June 1976, reprinted in 1976, ILM, vol. 15 967. The OECD periodically reviews and updates its guidelines. For the 2000 and 2011 reviews see, the OECD Declaration on International Investment and Multinational Enterprises 2000, reprinted in 2001, ILM, vol. 40, 237, and updated as, OECD Guidelines for Multinational Enterprises: Recommendations for Responsible Business Conduct in a Global Context, 25 May 2011.

<https://www.oecd.org/corporate/mne/48004323.pdf> accessed 28 August 2021; ILO, 'Tripartite Declaration of Principles Concerning Multinational Enterprises and Social Policy' (March 2017), $<$ http://www.ilo.org/wcmsp5/groups/public/--ed emp/---emp ent/multi/documents/publication/wcms 094386.pdf $>$ accessed 30 August 2021; UN Global Compact, 'Ten Principles of the UN Global Compact' available at $<$ https://www.unglobalcompact.org/what-is-gc/mission/principles $>$ (accessed 6 September 2021); Human Rights Council, The Guiding Principles on Business and Human Rights (UNGPs): Implementing the United Nations 'Protect, Respect and Remedy' Framework (21 March 2011) UN Doc. A/HRC/17/31.

${ }^{26}$ UN Norms on the Responsibilities of Transnational Corporations and Other Business Enterprises with Regard to Human Rights, UN Doc E/CN.4.Sub.2/2003/12/Rev.2 (30 August 2003).

${ }^{27}$ UNGPs, Supra $\mathrm{n} 25$.

28 ibid, principle 11 .
} 
relationships. The remedy aspect provides for greater access by victims to effective remedy. Yet there is a disconnect between the responsibility to respect human rights and the access of victims to effective remedy. This is because the responsibility to respect is framed in the form of an expectation and is not binding on corporate entities. Thus, if the corporate entities fail to execute their responsibility to respect by undertaking human rights due diligence in their business relationships, victims of any resulting abuse are left without a legal basis for holding corporate entities accountable.

It is with this background that renewed calls were made for an international instrument to regulate, in international human rights law, the activities of corporate entities- this time, with provisions on binding consequences for corporate entities who fail to observe human rights standards in their operations. In response to these calls, the Human Rights council at its $26^{\text {th }}$ session, established the IGWG to come up with a binding instrument to regulate in international human rights law, the activities of transnational corporations. ${ }^{29}$

During the first few sessions of the IGWG, several state delegates and members of civil society advocated for the inclusion of provisions directly regulating business activities in the areas of human rights within the proposed binding instrument. The inclusion of direct obligations would put an end once and for all to the ancient long debate on the position of corporations under contemporary international law. However, before considering the imposition of such obligations, it is pertinent to establish a sound rationale for their imposition.

The establishment of a sound rationale for the imposition of direct international human rights obligations on TNCs in a regulatory instrument is crucial to its adequacy and acceptance. This is especially so when considering the argument that corporations are established primarily to maximise profits, a factor that was at the fore of the arguments against other corporate social responsibility initiatives. Thus, any international regulatory initiative, which aims to directly regulate the activities of TNCs as they affect human rights, should provide logically sustainable and concrete rationales for doing so. The existing regulatory initiatives, however, do not address this important aspect but rather offer contestable rationales.

The OECD Guidelines and ILO Tripartite Declaration offer identical justifications as to why TNCs should have human rights responsibilities. According to these initiatives, TNCs are urged to observe human rights standards in their operations because of their potential to make important contributions to economic and social progress and to resolve the difficulties to which their various operations may give rise. ${ }^{30}$ These rationales have been referred to as the 'business case' for corporate responsibility. ${ }^{31}$

There is nothing fundamentally wrong with a 'doing well by doing good' approach, which the business case for corporate responsibility seems to suggest. After all, 'treating people well is conducive to productive long-term relationships, and productive long-term relationships are

\footnotetext{
${ }^{29}$ UN Human Rights Council, Supra $\mathrm{n} 1$.

${ }^{30}$ OECD Guidelines 2011, Supra n 25 at 3; ILO Declarations, Supra n 11, at para 2.

31 'In what has becomes known as the 'business case for Corporate Social Responsibility' the pitch is that a company can 'do well by doing good': that is, can perform better financially by attending not only to its core business operations but also to its responsibilities towards creating a better society.' - E. Kurucz, B. Colbelt and D. Wheeler, 'The "business case" for Corporate Social Responsibility' in Andrew Crane, et al, (eds.), The Oxford Handbook on Corporate Social Responsibility (Oxford University Press, 2008), 8.
} 
conducive to profits. ${ }^{32}$ But, the question that arises is whether observing human rights standards is always conducive to maximising profits? The answer to this question has to be answered in the negative. In the UCC-UCIL incident in Bhopal, it was alleged that the safety standards in the gas plants were deliberately lowered following cost saving measures undertaken by UCC that ultimately resulted in the loss of thousands of lives. ${ }^{33}$ In Ecuador, Chevron purportedly used substandard equipment and defective waste disposal methods with the aim of increasing their profit margins. Of course, this resulted in severe contamination of the environment and loss of livelihood of indigenous peoples. ${ }^{34}$ Similar situations were alleged to have resulted from the activities of Shell in Nigeria's Niger-Delta region. ${ }^{35}$

These examples demonstrate that there will often be times where a TNC can increase profits by engaging in behaviour that risks the lives of its workers and the individuals in the local communities in which they operate. It may not be realistic to focus on a business case that establishes a determinate connection between human rights and profit. Other than the fact that it may sometimes be impractical, the business case also threatens to undermine the entire fabric of human rights. As Langlois states, 'a right is not something that can be assigned on efficiency grounds,' it is 'precisely an individual's trump against the claims of efficiency' ${ }^{36}$ Thus, any initiative that 'attempts to place a calculable value on humans with a view to encouraging some sort of trade-off between human rights and other goals' is untenable. ${ }^{37}$

The Global Compact and the Guiding Principles, find their rationale for corporate human rights responsibility in social expectation and the public-private partnership. ${ }^{38}$ However, this will only be feasible where partnerships with the various stakeholders in society are necessary for the TNCs to achieve their own corporate objectives. The incorporation of human rights standards into the corporate system of operations would necessarily mean that TNCs would have to formulate new policies, train employees, monitor conduct, and take certain other actions- all, which would involve some extra expenditure on their part. It is unlikely that they would be inclined to conduct their operations according to societal expectations if such expectations will affect their businesses. After all, the maximisation of profit is still part of the ultimate objective of the corporation. The social expectation rationale is thus exposed to the same limitations as the business case as it places the ultimate decision on TNCs to choose whether or not it would respect internationally recognised legal rights.

Moreover, in a complex international society with varying levels of development, the social expectations will invariably differ from State to State. Developing States will always focus on standards that push for the increase in foreign direct investment, while developed States will advocate for corporate friendly standards for their corporate nationals. Standards including those relating to impacts of corporate activities on health and the environment would be

\footnotetext{
${ }^{32}$ C. McDonald, 'The “complex” business case for human rights' (Business Ethics Blog 15 May 2014)

<https://businessethicsblog.com/2014/05/15/the-complex-business-case-for-human-rights/> accessed 17 September 2021.

${ }^{33}$ M. Janis, 'The Doctrine of Forum Non Conveniens and the Bhopal Case' (1987) 34 Netherland International Law Review 2,1 .

${ }^{34}$ Amnesty International, Clouds of Injustice: Bhopal Disaster 20 years on (29 November 2004) AI-Index ASA

20/015/2004, 10- 18.

${ }^{35}$ M. Ezeudo, Supra n 10.

${ }^{36}$ R. Langlois, 'Cost-Benefit Analysis, Environmentalism and Rights' (1982) 2 Cato Journal 1, 283

<https://object.cato.org/sites/cato.org/files/serials/files/cato-journal/1982/5/cj2n1-9.pdf> accessed 24 August 2021.

${ }^{37}$ S. Deva, Regulating Corporate Human Rights Violations: Humanizing Business (Routledge 2014), 149.

${ }^{38}$ Global Compact and UNGPs, Supra n 25.
} 
relegated to the background. Thus, it would be difficult to determine appropriate expectations of corporate responsibility regarding human rights.

Also, persons in States that have been subjected to long years of systematic corruption and tyrannical rule may have adapted to the status quo and may have developed low expectations concerning compliance with human rights norms. In Nigeria, for example, systemic corruption of government officials has been widely documented. ${ }^{39}$ As a result of such widespread and long-term corruption, individuals within the country have developed lax attitudes in relation to the harmful activities of TNCs in the oil producing regions. The agitations of the people have greatly subsided as community leaders have been silenced by large pay-outs by these government officials. Thus, the system of corruption and abuse has become the norm. ${ }^{40}$ Yet, there are internationally recognised human rights norms proscribing these very situations as unacceptable despite the reduced social expectation of the people living therein. If human rights standards are accepted based on low societal expectations, then what will be obtainable would be a replication of the status quo that encourages human rights harm, rather than seeking to develop a world in which the human rights of individuals are fully protected, which is the single overarching objective of international human rights. ${ }^{41}$

This objective stems from the inherent dignity of the human person, as enshrined by the basic international human rights legal documents. ${ }^{42}$ These international legal documents articulate human rights from the perspectives of all individuals as beneficiaries of those rights. ${ }^{43}$ The rights are not particular as to who the agents required to realise them are, instead, they call on all others to both refrain from behaviour that would infringe on the rights and to assist in their realisation. ${ }^{44}$ However, early historical frameworks for the protection of human rights came up at a time when the State was generally assumed to be the only agent obligated to meet human rights claims. ${ }^{45}$ This was primarily due to the position the State occupied vis-à-vis individuals as the primary provider and controller of public goods, by virtue of which the State had the power and the opportunity to both promote and violate human rights. ${ }^{46}$

Nevertheless, the early assumptions have proved to be too simplistic. Due to the wave of globalisation the situation is now more complex. The position of the State as the primary violator and promoter of human rights is not absolute as non-state actors, including TNCs, have acquired similar positions. In the quest for foreign investment and its attendant benefits in a globalised and free market economy, States have delegated and outsourced powers and functions to TNCs. As a result, the wealth and influence of TNCs have greatly increased,

\footnotetext{
${ }^{39}$ D. Smith, A Culture of Corruption: Everyday Deception and Popular Discontent in Nigeria (Princeton University Press, 2007), xii.

${ }^{40}$ Ciara Hackett, 'The challenge of MNCs and development: oil extraction, CSR, Nigeria and Corruption' (2016) 2 Journal of Human Rights in the CommonWealth 2, 1-13 <https://pure.qub.ac.uk/portal/files/18340387/2260_3398_1_SM.pdf > accessed 17 September 2021.

${ }^{41}$ D. Kinley and J. Tidaki, 'From Talk to Walk: The Emergence of Human Rights Responsibilities for Corporations at International Law' (2004) 44 Virginia Journal of International Law 931-1023, 962-963.

${ }^{42}$ Preamble to the International Covenant on Civil and Political Rights (adopted 16 December 1966, entered into force 23 march 1976) 999 UNTS 171; Preamble to the International Covenant on Economic, Social and Cultural Rights (adopted 16 December 1966, entered into force 3 January 1976) 993 UNTS 3.

${ }^{43}$ D. Bilchitz, Poverty and Fundamental Rights (Oxford University Press, 2007), 74.

${ }^{44}$ A. Kuper (ed.), Global Responsibilities. Who Must Deliver on Human Rights? (Routledge, 2005), x.

45 ibid; International Council on Human Rights Policy (ICHRP), Beyond Voluntarism: Human Rights and the Developing International Legal Obligations of Companies (Versoix: ICHRP, 2002), 9.

46 ibid
} 
dwarfing that of many States. Consequently, TNCs also have the power as well as the opportunity to both promote and threaten human rights.

The ECOSOC resolution establishing the UN Draft Code has also noted that "while corporations are frequently effective agents for the transfer of technology as well as capital to developing countries, their role is sometimes viewed with awe, since their size and power surpass the host country's entire economy' and, 'the international community has yet to form a positive policy and establish effective machinery for dealing with issues raised by the activities of these corporations. ${ }^{47}$ The Draft UN Norms also hinged the need for the implementation of international human rights standards on the dual capacity of TNCs to foster economic well-being whilst at the same time causing harmful impacts on the human rights of individuals through their core business practices and operations. ${ }^{48}$ Thus, if the main objective of human rights is indeed the protection of the fundamental interests of individuals, then logically, there must be binding consequences for all agents who have the capacity to impact on them.

However, rather than placing obligations on TNCs, the international initiatives were couched in voluntary terms, merely encouraging and not compelling TNCs to comply with human rights in their activities. The UN Draft Norms was the only initiative that suggested obligations for TNCs. ${ }^{49}$ However, it was criticised for watering down the state obligations under international law- a criticism that has been referred to as the "dilution argument' ${ }^{50}$ Apart from the fact that TNCs must necessarily have obligations in order for the effective application of the States' obligation to protect, the idea that conferring international obligations on TNCs presents a shift in international law is unfounded.

Certain long-established multilateral treaties directly impose obligations on corporations. The 1969 Convention on Civil Liability for Oil Pollution Damage provides that the owner of a ship (which may be a company) shall be liable for any pollution damage caused by it. ${ }^{51}$ The 1982 UN Convention on the Law of the Sea prohibits not only States but also natural and juristic persons from appropriating parts of the seabed for its minerals. ${ }^{52}$ It has not been suggested that by adopting these provisions, states have diluted their own international obligations, contrarily, the drafters of these treaties have apparently considered companies to be such important international actors that in order to actualise the objectives of the treaty they had to be considered directly, in addition to States. ${ }^{53}$ Thus, even if the idea of imposing direct human rights obligations on TNCs may be seen as innovative, it would not be a move that can correctly be denounced as unorthodox.

\footnotetext{
${ }^{47}$ T. Weiss, 'The UN Code of Conduct for Transnational Corporations' in David P. Forsythe (ed.), The United Nations in the World Political Economy (New York; St Martin's Press, 1989), 87

${ }^{48}$ Preamble to the Draft Norms on Transnational Corporations, Supra n 25.

49 ibid

${ }^{50}$ A. Clapham Human Rights Obligations of Non-State Actors (Oxford University Press, 2006), 216.

${ }^{51}$ International Convention on Civil Liability for Oil Pollution Damage (adopted 29 November 1969, entered into force 19 June 1975) (BGBI, 1996 II S. 671: BGBI. 2002 II 943), article III ' ...the owner of a ship at the time of an incident, or where the incident consists of a series of occurrences at the time of the first such occurrence, shall be liable for any pollution damage caused by oil which has escaped or been discharged from the ship as a result of the incident.'

${ }^{52}$ UN Convention on the Law of the Sea (adopted 10 December 1982, entered into force 16 November 1994) 1833 UNTS 3 , article 137 (1):'No State shall claim or exercise sovereignty or sovereign rights over any part of the Area or its resources, nor shall any State or natural or juridical person appropriate any part thereof. No such claim or exercise of sovereignty or sovereign rights nor such appropriation shall be recognised.'

${ }^{53}$ Menno T. Kamminga, 'Corporate Obligations Under International Law' (Submission to the Office of the United States High Commissioner for Human Rights, September 2004), 3-4.
} 


\section{DIRECT OBLIGATIONS AND THE IGWG TREATY PROCESS}

The OP and indeed the zero draft largely depend on the cooperation of the state parties for the implementation of the proposed provisions. States themselves engage in commercial activities and may very well be a part of the violations perpetrated by business entities. In Nigeria, for instance, all subsidiaries of foreign oil companies operate based on joint venture agreements concluded with the Nigerian National Petroleum Corporation (NNPC), typically on a 60/40 percent ratio, with the NNPC owning the higher percentage. ${ }^{54}$ There are a plethora of reports on the NNPCs complicity with the foreign oil companies in perpetrating human rights violations in the country. Such complicity is usually attributed to the unwillingness and incapacity of the states to use their national structures to implement their international human rights obligations. ${ }^{55}$ There is no provision in the proposed articles of the zero draft and its OP where States' complicity in corporate human rights abuses is addressed. This could very well lead to situations where victims of corporate related human rights abuse are left without recourse to remedy, defeating the purpose of a binding instrument.

It should be recalled that the incapacity and unwillingness of states to carry out their obligations to hold business entities accountable for human rights abuses is the very reason for the initiation of this entire treaty process. ${ }^{56}$ Thus, this consideration should be at the forefront of any initiative for the implementation of human rights standards in the field of business and human rights. It would be an anomaly to let business entities 'off the hook' because the states have failed to carry out their international obligations. In such a situation, the only losing party are the victims in a regime where they are to be the primary focus of protections.

One good response to this legal conundrum would be to place direct human rights obligations on business entities. Indeed, this has been the opinion of several scholars on the subject of business and human rights, from the beginning of the treaty initiative. ${ }^{57}$. International law requires that states ensure that third-parties, including TNCs, comply with binding international human rights requirements, this would mean that the third parties themselves are necessarily obligated to comply with such requirements. ${ }^{58}$ If third parties did not have prior obligations to individuals, 'the state's derivative responsibility to hold them accountable would be empty and meaningless. ${ }^{59}$ There is no conceptual impossibility for corporations to directly acquire obligations under international law, as demonstrated by extant provisions in conventions on the law of the sea, environmental law and energy law that establish direct obligations for businesses. ${ }^{60}$ Even the Elements document discussed at the IGWG third session contemplated the imposition of such direct obligations.

\footnotetext{
${ }^{54}$ M. Ezeudu, Supra n 10.

55 ibid

56 ibid

${ }^{57}$ D. Bilchitz, 'The Necessity for a Business and Human Rights Treaty' (2016) 1 Business and Human Rights Journal 2.

58 ibid, 208.

59 F. Wettstein, Multinational Corporations and Global Justice: Human Rights Obligations of a Quasi-Governmental Institution (Stanford University Press, 2009), 285.

${ }^{60}$ United Nations Convention on the Law of the Sea (adopted 10 December 1982, entered into force 16 November 1994) 1833 UNTS 3, article 137 (1) 'No State shall claim or exercise sovereignty or sovereign rights over any part of the Area or its resources, nor shall any State or natural or juridical person appropriate any part thereof. No such claim or exercise of sovereignty or sovereign rights nor such appropriation shall be recognized'; International Convention on Civil Liability for Oil Pollution Damage (adopted 29 November 1969; entered into force 19 June 1975) 973 UNTS 3, article III 'the owner of a ship at the time of an incident, or where the incident consists of a series of occurrences at the time of the first such occurrence, shall be liable for any pollution damage caused by oil which has escaped or been discharged from the ship as a result of the incident'
} 
According to the Elements, 'the core of an international legally binding instrument' is the 'recognition of general obligations of TNCs and OBEs' to comply with all applicable laws and respect internationally recognised human rights. ${ }^{61}$ In its preamble, the zero draft proposed that 'all business enterprises, regardless of their size, sector, operational context, ownership and structure shall respect human rights, including by avoiding causing or contributing to adverse human rights impact through their own activities... ${ }^{62}$ The inclusion of the word 'shall' is generally understood to provide mandatory flavour, indicating the existence of an obligation. However, the provision is located in the preamble, which usually serves to provide context to the treaty and does not on its own have obligatory force. In its core provisions, the Zero Draft did not retain the approach in the Elements, the Zero Draft only mentioned corporate liability under the domestic law of the State Parties, and compelled States to strengthen domestic mechanisms for such liability. ${ }^{63}$ The 2019 Revised Draft and 2020 Second Revised Draft mirrored the position of the Zero Draft. They both focused on the State's obligation to regulate the activities of business entities as they affect human rights. ${ }^{64}$ The Third Revised Draft of the Binding Treaty on Business and Human Rights, which was released in August 2021, reaffirmed the obligations of States to respect, protect, fulfil and promote human rights within their territories ${ }^{65}$ It goes on to underline that 'all business enterprises, regardless of their size, sector, location, operational context, ownership and structure have the obligation to respect internationally recognized human rights. ${ }^{66}$ Nevertheless, like the Elements document, this provision is only captured in the preamble of the Third Revised Draft, thus it is without any binding force. Nevertheless, it leaves an option, in Article 15.5, for states to make further developments in pursuance of the implementation of the binding instrument. ${ }^{67}$ This, perhaps, creates a possibility of considering international implementation mechanisms that can directly address corporate human rights abuse in the future.

It is important to note that the establishment of direct corporate obligations does not suggest that State obligations would simply 'disappear'. Multiple participants in a wrongful act may have simultaneous and coexistent responsibilities, which require each participant to respond individually for their part in the wrongful act. ${ }^{68}$ Obligations of business entities are independent of the State's acceptance of human rights obligations. They are not also contingent on the

\footnotetext{
${ }^{61}$ OEIGWG, 'Elements for the draft legally binding instrument on transnational corporations and other business enterprises with respect to human rights' (29 September 2017) <https://www.ohchr.org/Documents/HRBodies/HRCouncil/WGTransCorp/Session3/LegallyBindingInstrumentTNCs_OBE s.pdf $>$ accessed 15 September 2021, 3 'General Obligations'.

${ }^{62}$ OEIGWG, Legally Binding Instrument to Regulate in International Human Rights Law, the Activities of Transnational Corporations and Other Business Enterprises' 'Zero Draft' (16 July 2018) https://www.businesshumanrights.org/sites/default/files/documents/DraftLBI.pdf > accessed 15 September 2021, article 1.

${ }^{63}$ Ibid, Article 9 and 10.

${ }^{64}$ OEIGWG, 'Legally Binding Instrument to Regulate, In International Human Rights Law, The Activities of Transnational Corporations and Other Business Enterprises; Revised Draft' (16 July 2019), Articles 5 and 6; OEIGWG, 'Legally Binding Instrument to Regulate, In International Human Rights Law, The Activities of Transnational Corporations and Other Business Enterprises; Second Revised Draft' (6 August 2020), Articles 5-8.

${ }^{65}$ OEIGWG, 'Legally Binding Instrument to Regulate, In International Human Rights Law, The Activities of Transnational Corporations and Other Business Enterprises; Third Revised Draft' (17 August 2021).

${ }^{66}$ Ibid, preamble.

${ }^{67} \mathrm{ibid}$

${ }^{68}$ Inter American Court of Human Rights, International Responsibility for the promulgation and Enforcement of laws in Violation of the Convention (Articles 1 and 2 of the American Convention on Human Rights). Advisory opinion 0C-14/94 of 9 December 1994, Series No. 14, para 56; Application of the Convention on the Prevention and Punishment of the crime of Genocide (Bosnia and Herzegovina v Serbia and Montenegro), Judgement [2007] ICJ Reports, 43, paras 419-420.
} 
State's fulfilment of its own human rights obligations. The commentary to Principle 11 of the Guiding Principles on Business and Human Rights confirms this when it states that

the responsibility to respect human rights is a global standard of expected conduct for all Business Enterprises wherever they operate. It exists independently of states' abilities and/or willingness to fulfil their own human rights obligations and does not diminish those obligations. And it exists over and above compliance with national law and regulations protecting human rights. ${ }^{69}$

This idea is also reflected in the OECD Guidelines for Multinational Enterprises, which provides that

states have the duty to protect, while enterprises should, within the framework of internationally recognised human rights, international human rights obligations of the communities in which they operate, as well as relevant domestic laws and regulations, respect human rights, avoid causing, prevent or mitigate human rights harm. ${ }^{70}$

The language used in these documents signifies that the failure or inability of a state to enforce relevant international human rights obligations does not mean that corporations should escape accountability for their activities that negatively impact on human rights. Hence, the inclusion of such direct obligations would only clarify what is already understood as the duty of corporations under international human rights law, when it states that corporate entities shall comply with and respect 'internationally recognised human rights wherever they operate, and throughout their supply chains'. ${ }^{71}$

It is clear from the existing instruments on international human rights, that from a conceptual point of view, human rights already envisages direct obligations for corporations. What they do not do, however, is suggest how the establishment of these obligations will be achieved as a matter of law.

In reality, the responsibility for the implementation and enforcement of the obligations contained in the instruments fall back on the State. In essence, the corporate entities do not attract international responsibility for their failure to carry out the obligations, rather it is the state that is required to do so. Thus, only the state can violate the obligations or incur international responsibility for a breach of the obligations. ${ }^{72}$

In some domestic systems, such international agreements have no effect on private actors unless it is implemented by the national legislative branch. ${ }^{73}$ While in others, international agreements may have domestic legal force only where the national constitutional provisions state so. ${ }^{74}$ The primary obligations are attached to the state parties, as they are the ones who

\footnotetext{
${ }^{69}$ UNGPs, Supra n 25, at principle 11.

${ }^{70}$ Organisation for Economic Cooperation and Development (OECD), OECD Guidelines for Multinational Enterprises, 29

June 2011, Chapter IV 'Human Rights'.

${ }^{71}$ Elements, Supra n 61, para 3.2.

${ }^{72}$ International Convention on the Law of the Sea (n 168,) article 139 'state parties shall have responsibility to ensure that activities in the area, whether carried out by state parties, or state enterprises or natural or juridical persons which possess the nationality of states parties or are effectively controlled by them or their nationals'

${ }^{73}$ J. Klabbers, International Law (Cambridge University Press 2013), 289.

74 ibid, 290.
} 
are to take steps to prohibit particular private conduct or react to violations when they occur. In these sorts of situations, including direct obligations on corporate actors in a binding instrument on TNCs and OBEs may not be very effective in improving their accountability as long as it is the state that will still be accountable for any breach of its provisions. In the face of states' unwillingness and incapacity to discharge their obligations to protect such an exercise may be in vain.

There are, however, instances where international law has held private actors responsible for breaches of international law. These are situations where the international community has established mechanisms to adjudicate on the international responsibility of private actors. A good example of this is in the field of international criminal law. The Nuremberg rules, for example, provided for individual criminal responsibility for crimes against peace, war crimes and crimes against humanity. ${ }^{75}$ The vast majority of prosecutions at Nuremberg were against state officials, some however, occurred against the managers of certain corporations implicated in Nazi activities. ${ }^{76}$ The corporations themselves did not face prosecution because the tribunal possessed jurisdiction only over natural persons. ${ }^{77}$ Nevertheless, it can be argued that if the jurisprudential lens through which one views the trial of the corporate managers is broadened, it could be reasonably concluded that the criminality of the corporations was recognised. Although there were no corporations in the docket at Nuremberg, the basis upon which the corporate managers were found guilty of committing international crimes was due to their participation in the criminal conduct of the corporations. When examining this very issue in the Kiobel case, Justice Leval observed that 'in at least three of those trials, tribunals found that the corporations violated the law of nations and imposed judgement on individual criminal defendants based on their complicity in the corporations' violations. ${ }^{78}$

The legal reasoning in the Nuremberg cases was a two-step process. For example, in the I.G Farben Trial, the Tribunal reached the conclusion that Farben had violated international law and then imposed liability on individual Farben executives and employees based on their complicity in Farben's violations. ${ }^{79}$ In Krupp, for example, the tribunal made repeated references to the collective intent of the Krupp Group, and mentioned the corporation's 'ardent desire' to employ slave labour in its factories. ${ }^{80}$ Thus, although none of the corporations were formally declared 'criminal organisations', nor subject to the Tribunal's jurisdiction, it could be argued that the judgements in the trials of the corporate executives suggest the possibility of attributing liability for international crimes to the corporations themselves, not just to their directors and other employees. ${ }^{81}$

More recently, there has been an institutionalisation of the Malabo Protocol, which entrusts the (yet to be established) African Court of Justice and Human Rights with the jurisdiction to

\footnotetext{
${ }^{75}$ Control Council Law No. 10 (December 20 1945), reprinted in 1 Trials of War Criminals Before the Nuremberg Military Tribunals, at xvi (1949) (hereinafter CCL No. 10 Trials).

${ }^{76}$ See United States v Flick, United States v Krauch (the IG Farben Case), and United States v Krupp, CCL No. 10 Trials, ibid, vols. 6-9 (1950-1953).

${ }^{77}$ United Nations, 'Charter of the International Military Tribunal- Annex to the Agreement for the Prosecution and Punishment of the Major war Criminals of the European Axis (8 August 1945) A/CN.4/5, Article 6.

${ }^{78}$ Kiobel v Royal Dutch Petroleum Co., 621 F.3d 111 (2d Cir. 2010) at 180 (Justice Leval, J. concurring) < http://osaka.law.miami.edu/ schnably/Kiobel-2d-Cir.pdf> accessed 1 September 2019.

${ }^{79}$ Ibid.

${ }^{80}$ The Krupp Case (1948), reprinted in 9 Trials of War Criminals Before the Nuremberg Military Tribunals 1 (1950), para 1440.

${ }^{81}$ A. Ramasastry, 'Corporate Complicity: From Nuremberg to Rangoon: An Examination of Forced Labour Cases and Their Impact on the Liability of Multinational Corporations' (2002)20 Berkeley Journal of International Law 91, 112.
} 
receive cases of international crimes committed by corporations. ${ }^{82}$ Although the basis for its establishment and the criteria for corporate liability are unclear, ${ }^{83}$ the mere fact that such an instrument is being contemplated is an indication of the international community's increasing interest and attention to the possibility and need for establishing an international body capable of sanctioning erring corporate entities.

The Elements document contemplated this sort of arrangement by including a proposal for the establishment of an international court on transnational corporations to promote, implement and monitor the provisions of the binding instrument. ${ }^{84}$ Unlike the Elements, the Zero Draft, Revised Draft, Second Revised Draft and Third Revised Draft did not contemplate any binding international enforcement mechanism. They do not contain proposals for the creation of an international court where victims can sue companies or where business executives and corporations can be criminally prosecuted. They do not even as much as provide for a mechanism for sanctions via the Committee. The international oversight mechanisms contemplated by the zero draft, revised draft and the second revised draft combine the selfreporting and non-binding review characteristic of early human rights governing states, together with their flaws. This could be the price of admission for a critical mass of states to ratify the future treaty. ${ }^{85}$

The value of broad State participation may supersede the value added of an international court, especially in the face of the disappointing performance of the International Criminal Court. ${ }^{86}$ The text of the draft treaty should be appealing to States as it puts them in the 'driver's seat' to adopt legislation of their own to meet broadly stated standards without any compulsory international oversight mechanism. ${ }^{87}$ Business entities are very likely to oppose a binding instrument with direct obligations. However, they are more likely 'to take a fresh look' at an instrument which reinforces a State-based approach to its implementation and enforcement. ${ }^{88}$

\section{CONCLUSION}

Negotiations on the future binding instrument on business and human rights have produced four Drafts and an Elements document so far. This demonstrates the commitment of States and other relevant stakeholders to engage and determine ways in which corporate accountability for human rights abuses can be ensured. However, discussions are still centred on State obligations in relation to corporate entities, losing sight of the fact that it is the unwillingness and inability of States to execute their obligations that led to the point of discussing an international binding instrument. Without clear provisions on mechanisms that would ensure that corporate entities are held directly responsible for their harmful actions so that victims are not left without recourse to remedy, what would be the value in continuing the treaty process?

\footnotetext{
82 Protocol on Amendments to the Protocol on the Statute of the African Court of Justice and Human Rights (Malabo Protocol) (2014) SIC/Legal/Min/7(1) Rev.1.

${ }^{83}$ A. Abas, 'The Proposed International Criminal Jurisdiction for the African Court: Some Problematic Aspects' (2013) 60 Netherlands International Law Review 1, 27-50.

${ }^{84}$ Elements Document, Supra n 63, Article 9. b.1.

${ }^{85}$ D. Cassel, 'At last a Draft Un Treaty on Business and Human Rights' (The Blog of international Judicial Assistance, 2 August 2018) <https://lettersblogatory.com/2018/08/02/at-last-a-draft-un-treaty-on-business-and-human-rights/> accessed 29 April 2019.

86 ibid

87 ibid

${ }^{88} \mathrm{ibid}$
} 
What would be the value of broad State and business participation in the treaty process if the States remain unwilling and unable to apply their national regulations in ensuring proper access to remedy and accountability of TNCs? Perhaps, the fact that the issue of business and human rights being at the centre stage of international discussions is a good starting point. The binding instrument could clarify that all business entities are bound under international human rights law to respect human rights. This will settle the debates on whether or not corporations have human rights obligations, an issue which is still debated today. Nevertheless, it is important that the stakeholders in the treaty process do not lose sight of the essence of introducing the process in the first place. In this regard, the current Draft does well to leave open the possibility of 'any further development' needed to implement the treaty ${ }^{89}$ in the face of states' incapacity and unwillingness to execute their obligations. Indeed, all hope may not be lost.

\section{REFERENCES}

Abas, A., 'The Proposed International Criminal Jurisdiction for the African Court: Some Problematical Aspects' (2013) 60 Netherlands International Law Review 1.

Amnesty International, 'Corporations' (Amnesty International.org) <https://www.amnesty.org/en/what-we-do/corporate-accountability/> accessed 15 September 2021.

Amnesty International, Clouds of Injustice: Bhopal Disaster 20 years on (29 November 2004) AI-Index ASA 20/015/2004.

Application of the Convention on the Prevention and Punishment of the crime of Genocide (Bosnia and Herzegovina v Serbia and Montenegro), Judgement [2007] ICJ Reports, 43.

Bilchitz, D., Poverty and Fundamental Rights (Oxford University Press, 2007).

Bilchitz, J., 'The Necessity for a Business and Human Rights Treaty' (2016) 1 Business and Human Rights Journal 2.

Bill C-300, An Act respecting Corporate Accountability for the Activities of Mining, Oil or Gas in Developing Countries, http://www.parl.gc.ca/HousePublications/Publication.aspx?Language=E\&Mode=1\&DocId $=3658424$ accessed 2 September 2021.

Cassel, D., 'At last a Draft Un Treaty on Business and Human Rights' (The Blog of international Judicial Assistance, 2 August 2018) <https://lettersblogatory.com/2018/08/02/at-last-adraft-un-treaty-on-business-and-human-rights/> accessed 29 April 2021.

Clapham. A. Human Rights Obligations of Non-State Actors (Oxford University Press, 2006).

Deva S., Regulating Corporate Human Rights Violations: Humanizing Business (Routledge 2014).

Ezeudu, M., 'Revisiting Corporate Violations of Human Rights in Nigeria's Niger Delta Region: Canvasing the Potential Role of the International Criminal Court' (2011) 11 African Human Rights Journal 1

French Due Vigilance Law 2017, available at < https://www.business-humanrights.org/en/latestnews/french-duty-of-vigilance-law-english-translation/> accessed 17 September 2021; Australian code of Conduct Bill 2000, <http://www.austlii.edu.au/au/legis/cth/bill/ccocb20002002248/> accessed 17 August 2021.

Hackett, Ciara, 'The challenge of MNCs and development: oil extraction, CSR, Nigeria and Corruption' (2016) 2 Journal of Human Rights in the CommonWealth 2, 1-13

\footnotetext{
${ }^{89}$ Third Revised Draft, Supra n 64, Article 15.5.
} 
<https://pure.qub.ac.uk/portal/files/18340387/2260_3398_1_SM.pdf > accessed 17 September 2021.

Idowu, A., 'Human Rights, Environmental Degradation and Oil Multinational Companies in Nigeria: The Ogoniland Episode' (1999) 17 Netherlands Quarterly of Human Rights 2

International Council on Human Rights Policy (ICHRP), Beyond Voluntarism: Human Rights and the Developing International Legal Obligations of Companies (Versoix: ICHRP, 2002).

International Covenant on Civil and Political Rights (adopted 16 December 1966, entered into force 23 March 1976) 999 UNTS 171

International Covenant on Economic, Social and Cultural Rights (adopted 16 December 1966, entered into force 3 January 1976) 993 UNTS 3.

Janis, M., 'The Doctrine of Forum Non Conveniens and the Bhopal Case' (1987) 34 Netherland International Law Review 2.

Jerbi, Scott, 'Business and Human Rights at the UN: What Might Happen Next?' (2009) 31 Human Rights Quarterly 299.

Joseph, S., 'Taming the Leviathans: Multinational Enterprises and Human Rights' (1999) 46 Netherlands International Law Review 2, 184.

Joseph, Sarah, 'Protracted lawfare: The tale of Chevron Texaco in the Amazon' (2012) 3 Journal of Human Rights and the Environment 1

Kalinoe, L. and M. J. Kuwimb, 'Customary Landowners Right to Sue for Compensation in Papua New Guinea and the Ok Tedi Dispute' (1997) 25 Melanesian Law Journal 65, 2.

Kamminga, T. Menno, 'Corporate Obligations Under International Law' (Submission to the Office of the United States High Commissioner for Human Rights, September 2004), 3-4.

Kimmerling J., 'Indigenous People and the Oil Frontier in the Amazon: The case of Ecuador, Chevron Texaco and Aguinda' (2006) International Law and Advocacy 413

Kinley, D. and J. Tidaki, 'From Talk to Walk: The Emergence of Human Rights Responsibilities for Corporations at International Law' (2004) 44 Virginia Journal of International Law 931-1023, 962-963.

Kinley, David and Junko Nolan 'Trading and Aiding Human Rights: Corporations in the Global Economy' (2007) 25 Nordic Journal of human rights Law 4.

Kiobel v Royal Dutch Petroleum Co., 621 F.3d 111 (2d Cir. 2010) at 180 (Justice Leval, J. concurring) < http://osaka.law.miami.edu/ schnably/Kiobel-2d-Cir.pdf $>$ accessed 1 September 2021.

Klabbers, J., International Law (Cambridge University Press 2013).

Kuper A. (ed.), Global Responsibilities. Who Must Deliver on Human Rights? (Routledge, 2005). Kurucz, B. Colbelt and Wheeler D., 'The "business case” for Corporate Social Responsibility' in Andrew Crane, et al, (eds.), The Oxford Handbook on Corporate Social Responsibility (Oxford University Press, 2008).

Langlois, R., 'Cost-Benefit Analysis, Environmentalism and Rights' (1982) 2 Cato Journal 1, $283<$ https://object.cato.org/sites/cato.org/files/serials/files/cato-journal/1982/5/cj2n19.pdf $>$ accessed 24 August 2021.

McDonald, C., 'The "complex" business case for human rights' (Business Ethics Blog 15 May 2014) <https://businessethicsblog.com/2014/05/15/the-complex-business-case-for-humanrights/> accessed 17 September 2021.

Organisation for Economic Cooperation and Development (OECD), OECD Guidelines for Multinational Enterprises, 29 June 2011, Chapter IV 'Human Rights'.

Protocol on Amendments to the Protocol on the Statute of the African Court of Justice and Human Rights (Malabo Protocol) (2014) SIC/Legal/Min/7(1) Rev.1. 
Ramasastry, A., 'Corporate Complicity: From Nuremberg to Rangoon: An Examination of Forced Labour Cases and Their Impact on the Liability of Multinational Corporations' (2002)20 Berkeley Journal of International Law 91.

Shelton, Dinah 'Protecting Human Rights in a Globalized World' (2002) 25 Boston College International and Comparative Law Review 2, 279-280.

Simons P. and A. Macklin, The Governance Gap: Extractive Industries, Human Rights and Home State Advantage (London, Routledge 2014).

Smith, D., A Culture of Corruption: Everyday Deception and Popular Discontent in Nigeria (Princeton University Press, 2007), xii.

Stauffer, B., 'Holding companies to account: Momentum builds for corporate human rights duties (Human Rights Watch, 2020) < https://www.hrw.org/world-report/2020/countrychapters/global-2\# > accessed 17 September 2021.

The Krupp Case (1948), reprinted in 9 Trials of War Criminals Before the Nuremberg Military Tribunals 1 (1950), para 1440.

UN Convention on the Law of the Sea (adopted 10 December 1982, entered into force 16 November 1994) 1833 UNTS 3

UN Human Rights Council, Elaboration of an international legally binding instrument on transnational corporations and other business enterprises with respect to human rights 25 June 2014 A/HRC/26/L.22/Rev.1.

UN Norms on the Responsibilities of Transnational Corporations and Other Business Enterprises with Regard to Human Rights, UN Doc E/CN.4.Sub.2/2003/12/Rev.2 (30 August 2003).

UNHCHR, 'Report by the Special Representative of the United Nations Secretary General on the issue of Human Rights and Transnational Corporations and Other Business Enterprises' (Report No. III, June 2007).

United Nations Convention on the Law of the Sea (adopted 10 December 1982, entered into force 16 November 1994) 1833 UNTS 3.

United States v Flick, United States v Krauch (the IG Farben Case)

United States v Krupp, CCL No. 10 Trials, ibid, vols. 6-9 (1950-1953).

US Corporate Code of Conduct Act, 1 H.R. 4596 (106 ${ }^{\text {th }}$ Congress Session): Corporate Code of Conduct Act, 7 June 2000 <https://www.govtrack.us/congress/bills/106/hr4596/text $>$ accessed 14 November 2016; Corporate Responsibility Bill (UK Bill), Bill no.129 of 2003.

Weiss, T., 'The UN Code of Conduct for Transnational Corporations' in David P. Forsythe (ed.), The United Nations in the World Political Economy (New York; St Martin's Press, 1989).

Weschka, W., 'Human rights and multinational enterprises: how can multinational enterprises be held responsible for human rights violations committed abroad?' 66 Zeitschrift fur auslandisches offentliches Recht und Volkerrecht 3.

Wettstein, J., Multinational Corporations and Global Justice: Human Rights Obligations of a Quasi-Governmental Institution (Stanford University Press, 2009).

Wilcox, M. Justice, 'Foreword' in M. Jones and P. Kriesler (eds)., Globalization, Human Rights and Civil Society (Prospect Media, 1998). 